\title{
The Role of Religion in the Lives, Agency, and Activism of Domestic Worker Leaders
}

\section{Susheela Mcwatts ${ }^{1}$}

\section{'SHORT BIO}

Dr Susheela Mcwatts has a PhD in Women's and Gender Studies from UWC and a Master's in Industrial Psychology from UWC. She is interested in paid labour, in particular domestic work, at the intersections of race, class, and gender. She is currently the Faculty Manager of the Arts and Humanities Faculty at UWC.

INSTITUTIONAL AFFILIATION

University of the Western Cape; smcwatts@uwc.ac.za

ORCID

https://orcid.org/0000-0001-6149-775X

ABSTRACT
$\begin{aligned} & \text { One of the key themes that emerged when researching domestic worker } \\ & \text { leader activism for my doctoral study, was the role of religion in developing } \\ & \text { agency among domestic worker leaders and religion's influence on their need } \\ & \text { to serve their constituents. Although Paulo Freire argues that traditional reli- } \\ & \text { gion can be fatalist and functions to preserve the status quo, the ability of reli- } \\ & \text { gious institutions to mobilise women is not a new phenomenon, nor is reli- } \\ & \text { gion's role in the liberation from other forms of oppression. In this article, I } \\ & \text { explore the role that religious institutions such as churches have played in } \\ & \text { shaping the activist identities of domestic worker leaders whom I have inter- } \\ & \text { viewed, and the centrality of religion in these women's lives, against a back- } \\ & \text { drop of their own life circumstances, the employers they worked for, and the } \\ & \text { larger political climate in their own countries. }\end{aligned}$

KEYWORDS

domestic workers; religion; activism; agency; transnational migration

Surely God does not change the condition of people until they change that which is in themselves

(Qur'an 13:viii)

(Painted on the wall of SADSAWU ${ }^{1}$ Hall at Community House).

Faith is the source of my power

(Iman Ali, the fourth Caliph)

(Painted on the wall of SADSAWU Hall at Community House).

\section{Introduction}

In many countries, domestic work as a profession is mainly a legacy of slavery that lasted throughout the colonial eras. In contemporary societies across the globe and countries across the North-South divide, domestic work remains a poorly paid activity, performed by marginalised groups of society - usually by women of colour who are rural migrants and easily exploited. In many Northern countries, migrants usually fill this need for low-skilled or unskilled labour and are often excluded from the

1 South African Domestic Services Workers Union. 
protection of important labour laws and regulations. In the Southern countries, local or other global Southern citizens from poorer and usually rural parts of the countries fill available domestic worker positions.

Events in the last decade on the global stage have heralded a new era for domestic workers, which have afforded them the voice as subaltern that has been silent until now. Despite being constructed as silent and as subjects without agency, unionised domestic workers organised themselves globally, becoming more visible and making their voices heard. This culminated in the establishment of the International Domestic Workers' Federation (IDWF) in October 2013. From 2013 to date, the IDWF has grown significantly and as of November 2021, the IDWF has 82 affiliates from 64 countries, representing more than 590,000 domestic/ household worker members. ${ }^{2}$

The IDWF was mainly formed to globally end the poverty and exploitation of domestic workers, with its strategic goal being the development of the capacity to defend and advance the rights and protection of its members in particular, and all domestic workers in general. Being part of the IDWF, enables domestic worker leaders to engender agency to secure economic, political, and legislative justice and challenge the stereotype of victims. Through their active campaigning to improve the lives of domestic workers, the IDWF became a site of resistance.

For my doctoral thesis, I analysed the subjective life stories of the executive members of the IDWF, to develop a better understanding of commonalities across contexts that might shape such agency and activist identity. ${ }^{3}$ However, theorising a feminist analysis of paid domestic work is complex and multifaceted. It requires the simultaneous, intersectional analysis of race, class, gender, nationhood, and citizenship, and a structural critique of how patriarchy and capitalism facilitate the subordination of women and reinforce exploitative relationships between women. After I have interviewed 11 of the 15 executive members of the IDWF, I found that religion would need to be added to any intersectional analysis on domestic worker leadership.

2 International Domestic Workers Federation, "About Us," https://idwfed.org/en/about-us1.

3 Susheela Mcwatts, "Yes madam, I can speak!' A study of the recovered voice of the domestic worker (PhD Thesis, University of Cape Town, 2018). 


\section{Research Design}

My doctoral study on which this article is based, was qualitative. ${ }^{4}$ I used in-depth and semi-structured interviews to highlight and understand the various voices and lived experiences of domestic workers. Drawing on the narratives of domestic worker leaders, my study was based on the Feminist Standpoint Theory and framed within transnational feminist practices. The central analytic component of the thesis was the voice of domestic workers as subalterns, centred particularly on their intersectional negotiations within the realms of their work. As my aim was to give these women voice through my research process, the feminist methodology was the most appropriate approach for this study, as it allowed me to render visible the complexities of the lives of domestic workers. The data derived from the in-depth interviews was analysed through the use of a thematic analysis.

Through the interviews, I attempted to track domestic worker leaders' paths of agency and the multiple sites of their resistance. Although I was conscious not to essentialise their experiences, I determined the commonalities that shaped their sense of self as leaders and their activism. I found that many domestic workers referred to God and to religion in their narratives. This article addresses the research question on what the role of religion is in the lives, agency, and activism of domestic worker leaders.

\section{Literature Review}

I have not been able to find any literature on the influence of religion on domestic worker activism. However, the ability of religious institutions to mobilise women is neither a new phenomenon, nor is religion's role in the liberation from other forms of oppression. Indeed, liberation theology which emerged in Latin America, ${ }^{5}$ focused on the role of human agency in the liberation from oppression. In the social sciences too, many scholars have documented how people pray to reduce stress, and that prayer affects their wellbeing positively. ${ }^{6}$ Elizabeth Ozorak, in her research on how women empower themselves through religion, also

Susheela Mcwatts, "'Yes madam, I can speak!"

5 Julius M. Gathogo, Latin American liberation theology: Does it fit in the schema of African theology of reconstruction?', Verbum et Ecclesia 42, no.1 (2021). 9 pages.

6 Susan Kwilecki, "Religion and coping: A Contribution from Religious Studies," Journal for the Scientific Study of Religion 43, no.3 (2004): 477-89. 
found that women use cognitive strategies and their faith to empower themselves in trying times. ${ }^{7}$

Religion can also have adverse effects on women's career advancement, as many women find themselves confined to domestic work. Nkosinathi Gama and Lodene Willemse argue that historically, religion has been one of the factors responsible for the inadequate educational opportunities offered to women. ${ }^{8}$ They refer to the USA as an example where women's education was directed towards studying the scriptures under male supervision and guidance, ensuring that they were not independent thinkers. They also argued that one of the other goals of American women's education historically was to ensure that they were capable of performing domestic tasks within the boundaries of marriage and child reproduction. ${ }^{9}$

\section{The Influence of Religion on Migration}

Many domestic workers are migrants, and religion has played an important role in their lives, being in a new destination. The role of religion in the migratory experience has been theorised since the 1950s by Oscar Handlin. ${ }^{10}$ According to Julien Debonneville, "religious belonging produces certain forms of symbolic capital and agency that impact all the stages of migration." ${ }^{11}$ God is constantly invoked from the departure to entry into the new country and everyday life. Margaret Magat contends that this is probably because migration is filled with adversity and crises. ${ }^{12}$ Magat explains:

7 Elizabeth W. Ozorak, "The Power, but not the Glory: How Women Empower themselves through Religion," Journal for the Scientific Study of Religion 35, no.1 (1996): 17-29; Paolo Freire, Pedagogy of the Oppressed (Continuum: New York, London, 1970). 119.

8 Nkosinathi Gama and Lodene Willemse, "A Descriptive Overview of the Education and Income Levels of Domestic Workers In Post-Apartheid South Africa," GeoJournal 80 (2015): 721-41.

$9 \quad$ Gama and Willemse, "A Descriptive Overview," 726.

10 Catharina P. Williams, "Female Transnational Migration, Religion and Subjectivity," Asia Pacific Viewpoint 49, no.3 (2008): 344-53.

11 Julien Debonneville, "A 'Minority' on the Move: Boundary Work among Filipina Muslim Migrant Domestic Workers in the Middle East," The Asia Pacific Journal of Anthropology 20, no.4 (2019): 3

12 Margaret Magat, "Teachers and 'New Evangelizers' for their Faith: Filipina Domestic Workers at Work in Italy," Paedagogica Historica 43, no.4 (2007): 603-24. 
The process of migration has been described as a "theologizing process" and studies have shown that immigrants not only continue their religious practices in the new country but become more religious than before. If they were not believers before migrating, they become believers when they migrate, with the church and its affiliated groups becoming surrogate extended families. Williams charges that while Handlin documented the significance of religion in immigrant communities in their new destination countries, he did not address the religious networks that support the migrants. Accessing spiritual resources, Williams argues, enables migrants to gain access to a diverse range of power. ${ }^{13}$

When women migrate, their subjectivities shift. Carol Gilligan argues that women acquire a sense of morality that favours care and connection. ${ }^{14}$ Her findings are corroborated by Claudia Liebelt's findings in a study of Filipina care workers in Israel. ${ }^{15}$ Liebelt argues that to understand the subjectivities of these women, "the understanding of the female political subject has to go beyond conceptualizations of either subordination or subversion, of either repression or resistance."16 Instead, she argues that the focus should be on women whose subject formation is embedded in Christian practices and morality, which prepare them for "the feminized, racialised and devalued employment niche of migrant care and domestic labour...Their ethical formation is deeply embodied and the remodelling of their envisaged selves ultimately depends on corporeal discipline and training." 17

\section{Domestic Worker Leaders as Servant Leaders}

I found when interviewing the domestic worker leaders in my study, that the Christian practices - care and connection - that both Gilligan and Liebelt speak of, often went hand in hand with a sense of servant leadership. However, I could not find any literature on domestic workers as servant leaders.

\footnotetext{
13 Magat, "Teachers and 'New Evangelizers," 607.

14 Carol Gilligan, In a Different Voice: Psychological Theory and Women's Development (Cambridge: Harvard University Press, 1993), 18-9.

15 Claudia Liebelt, "On Gendered Journeys, Spiritual Transformations and Ethical Formations in Diaspora: Filipina Care Workers in Israel," Feminist Review 97 (2011): 74-91.

16 Liebelt, "On Gendered Journeys," 88.

17 Liebelt, "On Gendered Journeys," 88.
} 
The term "servant leadership" was first coined by Robert Greenleaf. ${ }^{18} \mathrm{He}$ did not narrowly define the term but broadly encapsulated it as follows:

The Servant-Leader is a servant first...It begins with the natural feeling that one wants to serve, to serve first. Then conscious choice brings one to aspire to lead... The best test, and difficult to administer is this: Do those served grow as persons? Do they, while being served, become healthier, wiser, freer, more autonomous, and more likely themselves to become servants? And what is the effect on the least privileged in society? Will they benefit, or at least not further be harmed? ${ }^{19}$

The central feature of being a servant leader, according to Greenleaf, is going beyond one's self-interest. When people receive services and guidance from others, they will in turn serve and lead more people. The quest of the servant leader is to provide opportunities for followers to grow, while they are motivated by the need to serve. ${ }^{20}$ Greenleaf maintains that serving is vital for good leadership, while Saundra Reinke argues that it fosters a responsibility towards the community. ${ }^{21}$ According to Dirk Van Dierendonck "serving and leading becomes almost exchangeable. Being a servant allows a person to lead; being a leader implies a person serves."22

Chin-yi Chen, Chun-hsi Chen, and Chun-I Li maintain that spirit-centred leadership, including ethical leadership, spiritual leadership, servant leadership, and charismatic leadership, have many common characteristics, and can thus be classified as the transformational leadership schools. ${ }^{23}$ The transformational leadership theory stresses leaders' influence on followers, as the leaders "act through vision, intellectual

18 Robert K. Greenleaf, Servant Leadership: A Journey into the Nature of Legitimate Power and Greatness (New York: Paulist Press, 1977).

19 Greenleaf, Servant Leadership, 7.

20 Fred Luthans and Bruce Avolio, "Authentic Leadership Development, in Positive organisational scholarship, eds. Kim S. Cameron and Jane E. Dutton (San Francisco: Berrett-Koehler, 2003), 241-58.

21 Saundra J. Reinke, "Service before self: Towards a theory of servant-leadership," Global Virtue Ethics Review 3 (2004): 30-57.

22 Dirk Van Dierendonck, "Review of servant leadership," Journal of Management 37, no.4 (2011): 1232.

23 Chin-yi Chen, Chun-hsi Chen, and Chun-I Li, "The influence of Leader's Spiritual Values of Servant Leadership on Employee Motivational Autonomy and Eudemonic Well-Being," Journal of Religion and Health 52, no.2 (2013): 418-38. 
stimulation, inspiring motivations, and paying individual care" to inspire individuals. ${ }^{24}$

Larry Spears has identified ten characteristics of a servant leader, namely: 25

1) Listening - emphasising the importance of communication and seeking to identify the will of the people.

2) Empathy - understanding others and accepting how and what they are.

3) Healing - the ability to help make whole.

4) Awareness - being awake.

5) Persuasion - seeking to influence others, relying on arguments and not on positional power.

6) Conceptualising - thinking beyond the present-day need and stretching it into a possible future.

7) Foresight - foreseeing outcomes of situations and working with intuition.

8) Stewardship - holding something in trust and serving the needs of others.

9) Commitment to the growth of people - nurturing the personal, professional, and spiritual growth of others.

10) Building community - emphasising that local communities are essential in a person's life.

Judging by the ten characteristics above, these strands of servant leadership can be found in most domestic worker leaders' stories. However, I am mindful that this theory should not have a deleterious effect on the construction of domestic workers as leaders, as their identity construction is more complex. Furthermore, the terminology and concepts such as "a servant first" and "natural feeling wanting to serve" could harm the hard-won agency of domestic workers. These concepts might reinforce the negative stereotypes associated with domestic work, for instance, that marginalised sectors should want to serve others. I am also aware of the inherent contradiction that the Servant Leadership Theory has been formulated as a management theory for business leaders, and that domestic worker leaders have a working-class identity. 
The domestic worker leaders whom I have interviewed, had the propensity to attend to the needs of others, which can loosely be described as servant leadership, and I draw on some of their stories below.

\section{Stories from the Heart and the Influence of Religion}

\section{The Story of Marcelina}

I will start with the story of Marcelina Bautista. ${ }^{26}$ Marcelina was from Mexico and was 14 when she became a domestic worker. She came from a low-income family and had many brothers and sisters whom she had to support financially. Marcelina only completed primary school. To escape the grind of her intolerable work conditions, she joined a church group to learn handicrafts, where, extracting verses from the Bible, they reflected on their own lives as domestic workers. Marcelina says that the church gave her a new appreciation of domestic work and an understanding that she could take care of her family through domestic work, something she could not do otherwise. She learnt that domestic work was about a mission to serve and to rescue herself and others by taking back their rights. She also learnt that, although they were not respected as domestic workers, human rights in the workplace are extremely important.

A group of older domestic workers mentored her about domestic work and labour law issues, and by the age of 17, she was organising groups of domestic workers. She states: "So I continued with the working groups, I attended seminars, and my work was to contact other domestic workers, and we got up to 30 women and we went to spiritual retreats, so the retreats were very special, because for example, the priest would speak to us about gender, about sexuality, and self-esteem."

She thus learned about organising, an activity crucial in activism. She was subsequently invited to participate in a congress of domestic workers from Latin America and the Caribbean, where she learnt further leadership skills. She returned with increased skills to organise her peers and further her own and their education goals, the latter being very

26 The domestic workers whom I have interviewed, asked that their real names be used so as to spread the message of their activism and the work of the IDWF. 
important to her. Indeed, most Mexicans from poorer households emphasise education, and this is well documented. ${ }^{27}$

The empathy for her fellow domestic workers drives Marcelina's commitment to serve and support them. Being a domestic worker herself, she understands their poverty and suffering and the exploitative conditions under which they work. In September 2000, she opened a support, training, and personal development centre for domestic workers in Mexico City. When I interviewed her, the organisation was doing very well. Workers were able to attend training, find jobs, seek advice, and the centre also acted on their behalf in labour disputes.

\section{The Story of Elizabeth}

Elizabeth Tang, the General Secretary of the IDWF is a proponent of Freire's liberation theology. In my interview with her she describes how the principles of liberation theology that she learnt at university stayed with her long after she finished university. At university she joined the Catholic Student Federation, and in this organisation she learned about taking care of the poor and marginalised. Although she never worked as a domestic worker, she narrates that she also felt the need to serve. She needed to live Freire's teachings, and the best way to do that was to lend her voice to the plight of marginalised women. In Hong Kong, where she lives, she spent her entire life organising workers. In 1990, she formed the first migrant domestic workers' union, and has since then not stopped representing domestic workers. She maintains that "democracy" and "freedom" are principles by which one should live.

\section{The Story of Myrtle}

Wanting to serve, also plays a significant part in Myrtle Witbooi's activism. Myrtle is the President of the IDWF and the General Secretary of the South African Domestic Services Workers Union (SADSAWU). She is past the age where she could retire and do so comfortably. She says that her children have urged her to retire as they can support her financially. They think she deserves a rest and should spend time with them and her grandchildren. Besides, they say, she was not there for them when they were growing up as she was working and was a committed activist. However, Myrtle narrates that she is not ready to relax and just be a grandmother, as her work is still not done. Her

27 Jayne Howell, "The Dirt Came Up: Domestic Service and Women's Agency in Oaxaca City, Mexico," City and Society 29, no.30 (2017): 393-412. 
empathy for her peers, her desire to serve them by fighting against their oppression, and the suffering of migrant workers infuse her with the will and determination to carry on with her fight and makes her one of the more powerful domestic worker activists. Her desire to serve other domestic workers stretches back many years. As far back as 1974, she received the Fair Lady award for empowering other workers to speak for themselves - an example of her servant leadership. The award is even more surprising since it was obtained in apartheid South Africa.

Myrtle invoked God often in her interviews with me. She went to a Dutch Missionary School where she learnt to read and write, and she went to church regularly. Education was a tool used by missionaries to convert the coloured and African populations to Christianity, whilst the colonists, Gama and Willemse maintain, wanted Africans to be trained to be good labourers. ${ }^{28}$ It would serve the interests of the colonisers if the African population were tradition-bound with no formal education. ${ }^{29}$ This reasoning by the colonists was the basis for the "marginalisation of non-whites, particularly black Africans, which started in the colonial era and extended into the apartheid system." 30

Myrtle was taught by the missionaries how to read and write, but it was shocking for her when she got to know other illiterate domestic workers. She recalls: "That is when the idea came to me to ask them to ask their employers if we could do something on a Saturday, so that they could also learn to read and write. Then the Catholic Church heard about us, and they wanted to help us and that is when they set up this ABC ABED for domestic workers. It started with us, the domestic workers. We decided that we wanted to be educated and we decided we wanted to learn to read and write. That is where the Catholic Church and the Anglican Church got very involved. I remember travelling from Milnerton to Observatory to the Catholic Church where we used to sit on a Sunday afternoon with domestic workers. Lots of domestic workers used to come in there. We also had a training centre in Hanover Park where we used to teach domestic workers, mostly catering for domestic workers. That is how we became involved, but at that time, there were no labour laws."

Gama and Willemse, "A Descriptive Overview," 725-6.

Gama and Willemse, "A Descriptive Overview," 725-6.

Gama and Willemse, "A Descriptive Overview," 726. 
The church in Cape Town thus played a pivotal role in increasing the literacy levels of domestic workers at that time. Myrtle's overwhelming desire though, was to help domestic workers. She asserts: "Many people said to me that I should become a women's right activist, or fight for the empowerment of women, but this is what I like: Domestic workers' rights. There are still so many challenges, there are still so many things. Yes, we have fantastic labour laws, but how many domestic workers know about it? How many domestic workers understand it? The employers understand it, so that is our task. You see, we are working with people that for instance, if you give a domestic worker something to do, maybe she did not understand what you were saying, but she is not going to tell you. Late afternoon she will say to you, 'What was that word you said this morning, Sue?' Then you will realise that she was lost. Now you must have the patience to explain to her. Many people will not have that patience to explain to that worker. Whereas I, because I come from there, I understand how I had to learn."

Again, as in Marcelina's case, Myrtle felt that because she was also a domestic worker, she understood her peers and felt the need to help them, showing empathy and stewardship in her leadership style. She attributes her ability to speak out against injustice and not be scared to God: "I think there I discovered that God has given everyone a talent, and my talent was that I could speak and that I don't stand back for the government, and I didn't stand back for employers." Similarly, she attributes the fact that she does not hate her oppressors to God, saying that God blessed her not to hate. She instilled her deep faith in God in her children. She tells me of the time when her daughter was offered a job and did not know whether she could do it, how she went on her knees and asked God for help. Her daughter also went to the Pastor of her church to ask whether she should take the job. Even when Myrtle's son passed his final year at school and thanked her, she said, "God did it." Of her life now, especially the fact that her family is doing so well, she says, "God has been good to me, in fact, God has been great!"

Myrtle's audiences always comment on her ability to speak at large gatherings without any prepared notes. I have seen her in action a few times. She speaks passionately and eloquently, with her audience usually clapping at the incisive points she makes, and she regularly draws standing ovations. She attributes this ability to God. This ability to speak to large gatherings too, placed her on the road to lead workers. This is how it started, she claims, and it is God's doing: "I still didn't know 
that time that God has given me a talent. The night we had the meeting here in Salt River, in a hall, there were about 275 domestic workers, and he ${ }^{31}$ made a speech for me. I didn't know that I had this talent, and he gave me this speech. As I went to the stage, I had the speech in my hand, and all of a sudden I put the speech away and just started speaking, from who I am, and they didn't know that I was a domestic worker, and immediately, all of us just clicked. We started talking and the workers decided that I was the chairperson. I didn't know what a chairperson was."

After working as a domestic worker, she worked in a factory for a while. In the factory she also became a leader and attributes this to God: "My boss called all of us, 450 people, together to say that the union was there. I also just went to the meeting as I wanted to know what was going on. He said that the union negotiated that everyone got an increase, and I think God made me do it, but I put up my hand, and said, 'Excuse me, Sir, what union was here?' He said, 'Your union.' I again said, 'What union?' The girls were all looking at me, but the factory was just about eight months old. So, I said, 'Why do they come and speak to you? Why don't they speak to us?' I was just asking. All of a sudden, the workers started clapping. Then I said, 'I think we need to talk among each other. Why must we just accept what you are telling us here? I am sorry, Sir. I don't know how these workers feel, but this is the way I see it. This is not right what you are doing. You are actually imposing a R2.00 increase on us, ${ }^{32}$ and you don't ask us how we feel."

Myrtle showed many characteristics of servant leadership. She was aware of and understood the needs of her peers and was able to communicate them to make a difference. For both Myrtle and Marcelina, the belief in God influenced their leadership style. For Marcelina in particular, it was working closely with religious institutions that led to her servant leadership. For instance, Marcelina recounted: "Sometimes we are asked if we are born or are we formed into leadership, but what I am saying is that some we have, and some we learn. I learned a lot of things because of feeling sad because your work is not valued because your work is being discriminated against. So, I remembered the priest, Ivan, who was our priest who gave us the training and who spoke to us, not as a priest, but as a person who saw us as young people that had dreams

\footnotetext{
31 He was a journalist who became her best friend at the time.

32 South African currency.
} 
and had no other opportunities because of the work that we were doing, in my case, domestic work. We would always come in and share with him what happened during the week. We would say that the employers yelled at us, we couldn't go to school, as we worked too much, or sometimes we would say, 'I don't like this job anymore,' and he would say, 'You cannot feel bad because you are a servant,' and from our reflections, he would say to us that Jesus was also a servant to others, and that he turned the other cheek, but that we didn't really want to turn the other cheek. I think it helped us, little by little."

The priest thus compared their being domestic workers to the servanthood of Christ. Richard Osmer notes that "servant leadership is that which influences the congregation to change in ways that more fully embody the servanthood of Christ." 33 In this sense, the priest was the servant leader, as he influences his congregation to practise servant leadership. The biblical teaching is that a leader has to have the moral power and ability to be humble and willingly serve others, as demonstrated by Jesus who washed his disciples' feet.

As Marcelina and her peers were religious, the priest was able to quote from the Bible to make them feel better about themselves, by making them believe that what they did, mattered and how they mattered, as Christ mattered despite practising servanthood. In this way the stigma of doing domestic work was lessened. By invoking the Name of Christ, he gave them hope, and rationalised the fact that poor women were domestic workers and the exploitation that they had to endure.

\section{The Story of Lita}

Another domestic worker activist, Lita Anggraini, was raised in an upper middle-class family in Semarang, a city in Jakarta. She hated seeing poverty of those around her and it troubled her deeply. Her grandmother had a significant influence on her life. She narrates: "My family, especially my grandmother, educated us that we as human beings have a social function and if we do something, you must do it with all your heart, and with love, and you must give your life to the work that you do."

Her grandmother helped her neighbours who were poor and saw to the sick and needy in the neighbourhood. Lita attended university and

33 Richard R. Osmer, Practical theology: An Introduction (Grand Rapids: William B. Eerdmans, 2008), 192. 
studied in the Socio-Political Department. Although her parents expected her to find a job in the civil service after graduating, she became an activist and joined a political group. She noticed that poor women suffered the worst forms of oppression. To help alleviate the abuse and injustices that women faced, Lita and her friends formed the Yogyakarta Women's Discussion Forum. The military police, however, hounded them for organising demonstrations and for championing gender equality. Affected by the death of an abused domestic worker in 1992, Lita and her friends decided to concentrate on helping domestic workers.

What was striking about Lita was that she did not speak about her university education much, but about the education she received from her grandmother. With these values in mind, she made fighting against domestic worker exploitation her life's work. She assisted in opening a school for domestic workers that later became a network, and to which five unions were affiliated. She says that doing this was her duty as a woman, as a human being, as a worker, and as a citizen.

Lita chose not to get married, as she says she was too busy as an activist to look for and find a partner. She also mentioned that marrying young in Indonesia was a norm, and as she came from a middle-class family and was the only daughter, it was expected of her. However, her family came to understand her commitment to the domestic worker struggle and was happy as long as she was. This commitment to the marginalised is a feature of servant leadership apparent among most domestic worker leaders. Leadership often involves showing the example of self-sacrifice. Boas Shamir, Robert House, and Michael Arthur maintain that leaders might use self-sacrifice as an expression of loyalty and dedication to an organisation, or a cause, or as a symbolic expression of courage and conviction, and as a strategy to earn credibility and acceptance as a role model. ${ }^{34}$

\section{The Story of Antonio}

Antonio ${ }^{35}$ from Columbia was also only 15 when she started domestic work. She too showed a kindness and service to her employer who had Alzheimer's, and an empathy to her fellow workers that is reminiscent of

34 Boas Shamir, Robert House, and Michael B. Arthur, "The Motivational Effects of Charismatic Leadership: A Self-Concept Based Theory," Organization Science 4 (1993): 1-17.

35 Antonio did not provide me with her surname. 
servant leadership. She had the following to say: "I wanted to study or something like that, and I went back to another job taking care of an elderly lady, who suffered from Alzheimer's, but I liked taking care of her. If she didn't treat me well, I would think that she is just sick. For example, she would confuse me with someone at the factory that belonged to her husband. She thought that her husband had an affair, and she confused me with that lady, so she would try to kick me out of the house, hit me with a broom or stab me with a knife. After a while, I wanted to earn a little bit more money, but I didn't move because the husband could not find someone else who was patient with the lady as I did, so I had to stay for another year. I moved away to another family, but I regretted it because I felt it was a bad decision. They [her family] teach you that helping people is good. Since I was a little girl, I liked to help people and they said that it was okay to help people and I felt good doing it."

\section{Empathy and Kindness as part of Servant Leadership}

Myrtle showed a similar empathy and kindness to a baby that was burnt that she had to look after. She lived in the backroom of her employer's house in Sea Point. Sea Point is an affluent, ocean-facing suburb in Cape Town. After a year or two with her employers, she got married, but later divorced. As she says, "The trouble started when they said that my husband is not allowed to stay with me." She had a baby that her employer allowed her to keep, but her employer also had a child that was badly burnt and who cried a lot, and in the end, she could not cope taking care of both children. This badly burnt child was the reason for Myrtle giving up her dream of nursing too. She says, "I wasn't interested in nursing anymore because I was working with this family and their one child was badly burnt and wanted my attention, and I loved her very much, so I stayed with them for 12 and a half years."

She had to give her baby to her mother to take care of, as her employer was also going to have a baby and her baby had to be gone by the time her employer was going to give birth. The next time Myrtle saw her baby was when she was one year old and she stayed with Myrtle's mother until the age of 11. Myrtle worked all day and cooked for her employers and in the evening babysat their children, as they enjoyed going out. She shrugs off the unfairness of it all by saying, "Of course with apartheid laws, we couldn't go out late at night, there were no busses, we couldn't go to beaches, [except the dangerous rocky one], nothing like that, because apartheid laws prohibited domestic workers from doing anything 
like that. So that was my situation. You stayed in the backroom, reading books, and that is how you got educated, from reading."

Staying with her employers to assist in looking after this child, stems from Myrtle's religious background and her desire to serve those less fortunate than her. Similarly, Hester, the President of SADSAWU nursed her employer throughout his struggle with terminal cancer, having worked for the one family for 25 years and raising their only child. Indeed, care work deeply affects the lives of domestic workers. They enact the spiritual values of care and compassion.

The compassion that Marcelina felt for her fellow workers extended to extreme generosity. When she applied for and received a scholarship for three years with the MacArthur Foundation, ${ }^{36}$ she was expected to use the money to further her training on leadership or to attend courses at a university. Instead, she formed the Centre of Support and Training for Domestic Workers. She also used the scholarship to give 40 other domestic workers funding to attend workshops and training. At the end of the three years, she received another scholarship from the Ashoka Foundation for two years. ${ }^{37}$ With these funds, she was able to strengthen the base of her organisation. Marcelina practised servant leadership, where it was important to give back to her peers.

As she states, she could have taken the money, received further education and left. However, her commitment to the domestic worker fight would not allow her to do so. She believes she had many more opportunities than others, and she had to give back. Marcelina's story is more remarkable because insufficient money impacted her relationship with her husband, as he too did not have a stable income. Their marriage was put under great strain because of the financial instability. However, instead of keeping scholarships and funding that she received for herself, she shared it with her peers, reflecting her generosity of spirit and her servant leadership. I found the same generosity of spirit in Myrtle's story. Myrtle's husband "had a weakness for women," as she

36 "The MacArthur Foundation supports creative people and effective institutions committed to building a more just, verdant, and peaceful world. In addition to selecting the MacArthur Fellows, we work to defend human rights" (MacArthur Foundation, "25 Excellent Creative Visionaries Inspiring Change," n.d., https://www.macfound.org/).

37 "A global organization that identifies and invests in leading social entrepreneurs individuals with innovative and practical ideas for solving social problems" (Ashoka Southern Africa, "Website," n.d., https://www.ashoka.org/en). 
says and divorced her and married a much younger woman. Yet, she still helped him and his new wife to set up a business. Once again though, she attributed her selflessness to God, and said she was blessed because she did not hate.

\section{Religion as a Means to Silence}

Although religion has played an important part in the servant leadership of some domestic worker leaders, who also used the church as a vehicle of change and empowerment as witnessed in the stories above, many of the ordinary memberships of domestic workers, especially migrant workers, are silenced through the church because in many instances, the church functions to maintain the status quo. As my study was on domestic worker leaders and not the ordinary domestic worker group, I do not have concrete examples.

However, there are examples in the literature, such as a case study related to Filipino migrant workers that illustrate the more problematic discursive functioning of the church in maintaining and rationalising oppression, illustrating how the church can also act as an example of what Pierre Bourdieu termed "symbolic violence." ${ }^{38}$ The church can therefore be guilty of "the gentle, invisible form of violence, which is never recognized as such, and is not so much undergone as chosen, the violence of credit, confidence, obligation, personal loyalty, hospitality, gifts, gratitude, piety." ${ }^{39}$ It must be noted though, that it is not only the church that is culpable of practising symbolic violence. Employers usually do it as a matter of course. Many domestic workers feel obligated to their employers, as they receive food, second-hand clothes, and the occasional gift. Bourdieu calls it a "mode of domination" and argues that gentle violence is usually used "whenever overt, brutal exploitation is impossible." 40

The Iglesia ni Cristo is a Filipino church that has expanded to different parts of the world. Religion is very important to the Filipinos, as more than 80 percent of them are Catholic. ${ }^{41}$ Pinelopi Topali's study in Greece shows that although the church functions to uphold group solidarity in Filipino immigrant communities, it also serves to silence domestic work-

\footnotetext{
38 Pierre Bourdieu, Outline of a Theory of Practice (New York: Cambridge, 1977), 192.

39 Bourdieu, Outline of a Theory of Practice, 192.

40 Bourdieu, Outline of a Theory of Practice, 192.

41 Magat, "Teachers and 'New Evangelizers,"' 607.
} 
ers. It proposes that obedience is the ideal behaviour for women workers in the employer-employee relationship. ${ }^{42}$ The Iglesia ni Cristo forbids its members from joining labour unions. According to Topali, the church itself takes on the function of recruitment agency and the labour union. The church can demand obedience because besides the Filipino nation being mainly religious, there are businesses in the Philippines that only employ church members, as they are the idealised workers. They have to apologise to the church and the businesses they are employed to if their work is deemed unsatisfactory.

In Greece, the church prohibits its members from joining labour unions and recruitment agencies. It also forbids its members from joining the Filipino Workers Association, KASAPI-Hellas, a dynamic immigrant association. Reminiscent of the injunction to Marcelina to follow the example of Christ, Topali maintains that the church requires that "employees are supposed to obey and serve their employers as they serve Christ: like slaves." ${ }^{33}$ An official of the church is quoted: "OK, here slaves are the servants. Be obedient to those who are your masters. With good will rent your services as to the Lord. So, the doctrine here, the teaching here is that the servants or the employees when they are working, they should be working as if they are serving Christ himself." 4 The official added: "Slaves obey your human master with fear...and do with a sincere heart as though you were serving Christ. Imagine that? Do this not only when they are watching you because you want to gain their approval, but with all your heart do what God wants as slaves of Christ. Do your work cheerfully as though you serve the Lord." 45

When questioned on how the Greek employers react to the obedience of their workers, the official said: "She will see that this girl of mine never complains and always does her job and even more than I ask her. And even if she doesn't have a good behavior in the beginning, slowly-slowly she will change. She will become calm and she will love her. And she'll say that this servant is the best l've ever had." ${ }^{6}$

42 Pinelopi Topali, "Silent Bodies in Religion and Work: Migrant Filipinas and the Construction of Relational Power," Religions 4 no.4 (2013): 621-43.

43 Topali, "Silent Bodies in Religion and Work," 627.

44 Topali, "Silent Bodies in Religion and Work," 628.

45 Topali, "Silent Bodies in Religion and Work," 628.

46 Topali, "Silent Bodies in Religion and Work," 631. 
Of course, not all workers have bought into the church's ethos. As an informant told Topali: "Yes, sometimes the way they talk, sometimes they talk harshly when you know yourself that you are not stupid at all, and they treat you as one. But we are not slaves! That's sometimes... [laughing]...but...we have to accept that we are helpers... and that we suffer."

This church in Greece functions to exact the obedience from its immigrant community. In similar vein, Magat's study of the Filipino community in Rome also examined the notion of servanthood, and how the gendered interpretation of servitude has a bearing on the belief about domestic worker subservience. ${ }^{48}$ Like the domestic worker leaders in my study, domestic workers in her study are involved in church activities because of a belief in God and the church's services. The state structures do not provide migrant workers much assistance in Italy, however, the church plays a significant role in assisting them with services. The church is also a "microcosm of Filipino society, offering familiar cultural traditions, fellowship and belonging." 49 As in Greece, the clergies in Rome also act as employment agencies for migrant domestic workers. However, the services rendered are accompanied by the demand for religious servitude. Magat quotes the following passage from the Bible that is used to justify the subservience of domestic workers: "Slaves, be obedient to your human masters with fear and trembling, in sincerity of heart, as to Christ...knowing that each will be requited from the Lord for whatever good he does, whether he is slave or free."

Magat argues that there is no doubt that the Catholic Church in Rome allowed the Filipino immigrants to succeed. However, their biblical understanding of servitude within a colonial cultural context has subjected the Filipino domestic workers to obedience and servitude, to the extent that some workers compare their suffering with that of Jesus Christ. ${ }^{51}$ However, the Catholic Church is also known to be progressive in its fights against oppression globally. Both the Catholic and Anglican churches played a significant role in assisting black people in fighting against injustices in apartheid South Africa and had a role in the

\footnotetext{
Topali, "Silent Bodies in Religion and Work," 635.

Magat, "Teachers and 'New Evangelizers," 608.

Magat, "Teachers and 'New Evangelizers,"' 608.

Magat, "Teachers and 'New Evangelizers,"' 610.

Magat, "Teachers and 'New Evangelizers,"' 610.
} 
liberation struggle. This is also evident from the interview that I conducted with Myrtle, where she mentioned that they sought assistance from the Catholic Church to provide literacy programmes for domestic workers. Nevertheless, the church, especially the Catholic Church, is a patriarchal institution, and the servitude it exacts is gendered, particularly in respect of domestic workers.

However, despite the domestic servitude that workers are conditioned to display, they are still able to develop agency primarily through education. Magat recounts the story of Selica, who worked in Italy since she was 14 years old and dreamt of going to college. ${ }^{52}$ However, she was not allowed to leave the house, except on her free days, and even then, she received extra tasks from her employer to complete. Her aunt, though, discouraged her from telling her employer her dreams to study further. Instead, she advised her to suffer and offer her dreams to God and to shoulder the imperfections of her employer as a spiritual challenge. To her aunt's dismay, Selica had the strength to confront her employer several times. She attributed this confidence to each of the travel experiences that she had. Each travel experience brought its education, while a sense of self-esteem and agency often accompanies knowledge.

\section{Conclusion}

It is evident that religious institutions such as churches can play a significant role in shaping identities as it is evident in the centrality of religion in the lives of the abovementioned women. Religion has the power to transform women's lives and can either lead to empowerment or domination. It is evident in the lives of domestic worker leaders that being religious and being educated through religious institutions, helped to empower them on their roads to activism.

\section{References}

Ashoka Southern Africa. Website. n.d. https://www.ashoka.org/en (Accessed 1 December 2021).

Bourdieu, Pierre. Outline of a Theory of Practice. New York: Cambridge, 1977.

52 Magat, "Teachers and 'New Evangelizers," 611. 
Chen, Chin-yi, Chun-hsi Chen, and Chun-I Li. "The Influence of Leader's Spiritual Values of Servant Leadership on Employee Motivational Autonomy and Eudemonic Well-Being." Journal of Religion and Health 52, no.2 (2013): 418-38.

Debonneville, Julienne. "A 'Minority' on the Move: Boundary Work Among Filipina Muslim Migrant Domestic Workers in the Middle East." The Asia Pacific Journal of Anthropology 20, no.4 (2019): 344-61.

Freire, Paolo. Pedagogo of the Oppressed. New York: Continuum. 1970.

Gama, Nkosinathi and Lodene Willemse. "A Descriptive Overview of the Education and Income Levels of Domestic Workers in PostApartheid South Africa." GeoJournal 80 (2015): 721-41.

Gathogo, Julius M. "Latin American Liberation Theology: Does it Fit in the Schema of African Theology of Reconstruction?' Verbum et Ecclesia 42, no.1 (2021). 9 pages.

Gilligan, Carol. In a Different Voice: Psychological Theory and Women's Development. Cambridge: Harvard University Press, 1993.

Greenleaf, Robert K. Servant Leadership: A Journey into the Nature of Legitimate Power and Greatness. New York: Paulist Press, 1977.

Howell, Jayne. "The Dirt Came Up: Domestic Service and Women's Agency in Oaxaca City, Mexico." City and Society 29, no.30 (2017): 393-412.

International Domestic Workers Federation. "About Us." https://idwfed.org/en/about-us-1 (Accessed 1 December 2021).

Kwilecki, Susan. "Religion and Coping: A Contribution from Religious Studies." Journal for the Scientific Study of Religion 43, no.3 (2004): 477-89.

Liebelt, Claudia. "On Gendered Journeys, Spiritual Transformations and Ethical Formations in Diaspora: Filipina Care Workers in Israel." Feminist Review 97 (2011): 74-91. 
Luthans, Fred and Bruce Avolio. "Authentic Leadership Development. In Positive Organisational Scholarship, edited by Kim S. Cameron and Jane E. Dutton, 241-58. San Francisco: Berrett-Koehler, 2003.

MacArthur Foundation, "25 Excellent Creative Visionaries Inspiring Change." n.d. https://www.macfound.org/ (Accessed 1 December 2021).

Magat, Margaret. "Teachers and 'New Evangelizers' for their Faith:

Filipina domestic Workers at Work in Italy." Paedagogica Historica 43, no.4 (2007): 603-24.

Mcwatts, Susheela. "Yes Madam, I Can Speak!' A Study of the Recovered Voice of the Domestic Worker." PhD Thesis, University of Cape Town, 2018.

Osmer, Richard R. Practical Theology: An Introduction. Grand Rapids: William. B. Eerdmans, 2008.

Ozorak, Elizabeth W. "The Power, but not the Glory: How Women Empower themselves through Religion." Journal for the Scientific Study of Religion 35, no.1 (1996): 17-29.

Reinke, Saundra J. "Service before Self: Towards a Theory of ServantLeadership." Global Virtue Ethics Review 3 (2004): 30-57.

Shamir, Boas, Robert House, and Michael B. Arthur. "The Motivational Effects of Charismatic Leadership: A Self-Concept Based Theory." Organization Science 4 (1993): 1-17.

Topali, Pinelopi. "Silent Bodies in Religion and Work: Migrant Filipinas and the Construction of Relational Power." Religions 4, no.4 (2013): 621-43.

Van Dierendonck, Dirk. "Review of Servant Leadership." Journal of Management 37, no.4 (2011): 1228-61. doi:

$10.1177 / 0149206310380462$.

Williams, Catharina P. "Female Transnational Migration, Religion and Subjectivity." Asia Pacific Viewpoint 49, no.3 (2008): 344-55. 